Gut, 1985, 26, 770-775

\title{
Effect of cimetidine and omeprazole on aspirin- and taurocholate-induced gastric mucosal damage in the rat
}

\author{
R J UTLEY, A S M SALIM, AND D C CARTER \\ From the University Department of Surgery, Royal Infirmary, Glasgow
}

SUMMARY The effect of varying doses of cimetidine and omeprazole, on acute gastric mucosal lesions produced by topical aspirin $(200 \mathrm{mg} / \mathrm{kg} ; 1 \mathrm{ml} / 100 \mathrm{~g})$ in $0.175 \mathrm{M} \mathrm{HCl}$ or topical sodium taurocholate $(40 \mathrm{mM} ; 1 \mathrm{ml} / 100 \mathrm{~g})$ in $0.175 \mathrm{M} \mathrm{HCl}$ was studied in the pylorus ligated rat. Preliminary studies revealed dose dependent inhibition of acid secretion with both cimetidine and omeprazole. Intraperitoneal cimetidine $50 \mathrm{mg} / \mathrm{kg}$ and $100 \mathrm{mg} / \mathrm{kg}$ given before topical acidified aspirin reduced mucosal lesions from a control score of $23.7 \pm 3.5$ (mean $\pm \mathrm{SEM}$ ) in which $83 \%$ of stomachs contained lesions, to $6.9 \pm 2.2$ and $3.5 \pm 2 \cdot 1$ respectively $(\mathrm{p}<0.05), 36 \%$ and $27 \%$ of stomachs containing lesions. A dose of $250 \mathrm{mg} / \mathrm{kg}$ failed to reduce lesion score significantly $(17 \cdot 8 \pm 4.9)$ and $64 \%$ of stomachs contained lesions. Taurocholate-induced lesion score was reduced from a control value of $32.7 \pm 4.3$ in which $97 \%$ of stomachs contained lesions to $10 \cdot 8 \pm 3 \cdot 3$ and $15 \cdot 5 \pm 3.8$ by cimetidine $10 \mathrm{mg} / \mathrm{kg}$ and $25 \mathrm{mg} / \mathrm{kg}$ respectively $(\mathrm{p}<0.05), 62 \%$ and $68 \%$ of stomachs containing lesions. Cimetidine $50 \mathrm{mg} / \mathrm{kg}$ and $100 \mathrm{mg} / \mathrm{kg}$ failed to significantly reduce mucosal damage. Intraduodenal omeprazole $(1.25$ to $50 \mu \mathrm{mol} / \mathrm{kg})$ given before topical acidified aspirin or taurocholate failed to reduce mucosal lesions, as did intragastric omeprazole 5 $\mu \mathrm{mol} / \mathrm{kg}$ and $50 \mu \mathrm{mol} / \mathrm{kg}$ given before acidified aspirin. Cimetidine showed cytoprotective properties over a specific dose range beyond which the effect was lost despite continuing suppression of acid secretion. Omeprazole exhibited no cytoprotective activity.

Prostaglandins can protect the gastric mucosa against experimental injury by a mechanism independent of inhibition of acid secretion that has been termed 'cytoprotection'.' Cytoprotective activity has also been claimed for other antisecretory compounds such as the histamine $\mathrm{H}_{2}$-receptor antagonist, but the cytoprotective properties of cimetidine remain controversial. Carmichael et $a l^{2}$ found that cimetidine did not significantly reduce the incidence of gastric mucosal erosions induced in rats by topical aspirin and $\mathrm{HCl}$, while Robert et $a l^{3}$ found that cimetidine was protective only near antisecretory doses and in the presence of physiological concentrations of exogenous $\mathrm{HCl}$. Guth et al, ${ }^{4}$ however, found that cimetidine given parenterally in doses which did not affect acid secretion, protected pylorus-ligated rats against gastric erosions induced by topical aspirin in $0.15 \mathrm{~N} \mathrm{HCl}$. Kauffman and Grossman $^{5}$ found that in the pylorus-ligated rat

Address for correspondence: Mr R J Utley, FRCS, University Department of Surgery, Royal Infirmary, Glasgow G31 2ER. Scotland.

Received for publication 10 September 1984. parenteral cimetidine prevented dose dependent antral ulceration induced by intravenous administration of acetylsalicylic acid during gastric perfusion with $0.15 \mathrm{~N} \mathrm{HCl}$. Although histamine $\mathrm{H}_{2}$-receptor antagonists do not affect net transmucosal ion flux across mammalian gastric mucosa under basal conditions or during damage by agents such as sodium taurocholate, ${ }^{6}$ O'Brien and Silen ${ }^{7}$ showed that inhibition of acid secretion by these compounds significantly decreased the tolerance of amphibian gastric mucosa exposed in vitro to exogenous $\mathrm{H}^{+}$on its luminal aspect.

The aim of the present study was to re-examine in more than one model, the relationship between antisecretory activity and any gastric protection afforded by cimetidine, and to determine whether the new potent antisecretory agent, omeprazole possesses cytoprotective properties.

\section{Methods}

ANIMALS

Sprague-Dawley rats weighing 125-250 g were 
fasted for 48 hours before study. They were allowed free access to water and were housed in cages with wide mesh wire bottoms to prevent coprophagy.

SOURCE AND PREPARATION OF DRUGS

The doses of cimetidine were prepared from ampoules containing $200 \mathrm{mg} / 2 \mathrm{ml}$ (Smith Kline \& French Laboratories Ltd., England) by dilution with distilled water. Omeprazole (Hassle AB, Sweden) was prepared daily by dissolving $68.8 \mathrm{mg}$ of omeprazole in $5 \mathrm{ml} 100 \%$ polyethylene glycol 400 (PEG) which was then diluted with $5 \mathrm{ml}$ of distilled water containing $0.56 \mathrm{mg} \mathrm{NaHCO} / \mathrm{ml}$. Subsequent dilutions were prepared by adding $50 \%$ PEG solution containing $0.56 \mathrm{mg} \mathrm{NaHCO} / \mathrm{ml}$.

Acidified aspirin suspension was prepared by adding $2 \mathrm{~g}$ of aspirin (Evans Medical Ltd., Liverpool), $2 \mathrm{~g}$ of methylcellulose 20 (BP), and 1.5 $\mathrm{ml} 11.7 \mathrm{M} \mathrm{HCl}$ to $100 \mathrm{ml} 0.9 \% \mathrm{NaCl}$. Acidified sodium taurocholate solution was prepared by dissolving $1.07 \mathrm{~g}$ sodium taurocholate (Koch-Light Laboratories Ltd, England) in $50 \mathrm{ml} 0.9 \% \mathrm{NaCl}$ containing $0.75 \mathrm{ml} 11.7 \mathrm{M} \mathrm{HCl}$. In preliminary studies these doses of acidified aspirin or taurocholate produced greater than $85 \%$ incidence of gastric erosions and were considered a suitable basis from which to show inhibition.

\section{SECRETORY STUDIES}

Rats were anaesthetised with ether and pyloric ligation was done through a midline abdominal incision, care being taken not to interfere with the blood supply of the stomach or duodenum. The abdomen was closed and $2 \mathrm{ml} 0.9 \% \mathrm{NaCl}$ were instilled into the stomach by orogastric intubation and the animals allowed to recover from anaesthesia. Two hours later they were killed by ether overdose, the stomachs removed, the gastric contents carefully collected and measured, and $\mathrm{H}^{+}$ concentration determined by titration to $\mathrm{pH} 7 \cdot 0$ with $0.1 \mathrm{~N} \mathrm{NaOH}$ using an automatic titrator (Radiometer, Copenhagen). Gastric acid secretion was calculated for each animal and expressed as $\mu \mathrm{mol} / \mathrm{h}$.

The study evaluated the antisecretory effect of intraperitoneal cimetidine $(2,10,25,50,100$, and $250 \mathrm{mg} / \mathrm{kg}$ ) or intraduodenal injection of omeprazole $(1 \cdot 25,2 \cdot 5,5,10$, and $50 \mu \mathrm{mol} / \mathrm{kg})$ administered immediately after pyloric ligation, and of intragastric omeprazole ( 5 and $50 \mu \mathrm{mol} / \mathrm{kg}$ ) given 30 minutes before pyloric ligation. Control animals received the vehicle solution alone.

\section{CYTOPROTECTIVE STUDIES}

Pyloric ligation was done through a midline abdominal incision under ether anaesthesia. The abdomen was closed and acidified aspirin suspension (200 $\mathrm{mg} / \mathrm{kg}$ in $0.175 \mathrm{M} \mathrm{HCl} ; 1 \mathrm{ml} / 100 \mathrm{~g}$ ) or acidified sodium taurocholate solution $(40 \mathrm{mM}$ in $0.175 \mathrm{M}$ $\mathrm{HCl} ; 1 \mathrm{ml} / 100 \mathrm{~g}$ ) was instilled into the stomach by orogastric intubation. Two hours later the rats were killed by ether overdose and the stomachs were removed and opened along the greater curvature. After washing with a direct stream of cold water the stomachs were pinned out and examined for the presence of mucosal lesions by a person unaware of the type and dose of agent administered. A $\times 2$ hand lens was used to locate and score the lesions. Each lesion was measured in maximum length and width and the surface area $\left(\mathrm{mm}^{2}\right)$ calculated. The total lesion score was obtained for each animal and the mean lesion score calculated for each study group.

The study evaluated the cytoprotective effect of intraperitoneal cimetidine $(2,10,25,50,100$, and $250 \mathrm{mg} / \mathrm{kg})$ or intraduodenal omeprazole $(1 \cdot 25,2 \cdot 5$, 5,10 , and $50 \mu \mathrm{mol} / \mathrm{kg}$ ) administered immediately after pyloric ligation, and of intragastric omeprazole ( 5 and $50 \mu \mathrm{mol} / \mathrm{kg}$ ) given 30 minutes before pyloric ligation. Control animals recieved the vehicle solution alone. In order to minimise day-to-day variation in response to treatment, animals were allocated to the control and all of the treatment groups within the individual experiment on each experimental day.

\section{STATISTICAL ANALYSIS}

Results are expressed as mean \pm SEM. Data were analysed using analysis of variance. The MannWhitney test was used to determine whether results in a particular group were significantly different from those in the corresponding control group. Statistical significance was claimed when $\mathrm{p}<0.05$.

\section{Results}

\section{SECRETORY STUDIES}

Dose dependent inhibition of $\mathrm{H}^{+}$secretion was produced by cimetidine; a maximum of $90 \%$ inhibition relative to control values was noted with 50 $\mathrm{mg} / \mathrm{kg}$. Individual Mann-Whitney tests between the control group and each treatment group showed that all but the $2 \mathrm{mg} / \mathrm{kg}$ group differed significantly from controls in terms of acid output (Table).

Intraduodenal omeprazole inhibited $\mathrm{H}^{+}$secretion when doses greater than $1.25 \mu \mathrm{mol} / \mathrm{kg}$ were used. A maximum reduction of $94 \%$ relative to control values was obtained with $50 \mu \mathrm{mol} / \mathrm{kg}$ of omeprazole. Only the effect of the 10 and $50 \mu \mathrm{mol} / \mathrm{kg}$ doses reached statistical significance on individual Mann-Whitney testing (Table).

The results of intragastric omeprazole given 30 minutes before pyloric ligation are presented in the Table. Fifty micromoles per kilogram of omeprazole 
Table Effect of cimetidine and omeprazole on gastric acid output ( $\mu \mathrm{mol} / \mathrm{h})$ in the pylorus-ligated rat. Results are expressed as the mean $\pm S E M$ and $n$ indicates the number of rats in each group.

\begin{tabular}{|c|c|c|c|c|c|c|c|}
\hline \multicolumn{8}{|c|}{ Intraperitoneal cimetidine $(\mathrm{mg} / \mathrm{kg})$} \\
\hline & Control & 2 & 10 & 25 & 50 & 100 & 250 \\
\hline $\mathrm{n}$ & 8 & 10 & 10 & 10 & 10 & 7 & 8 \\
\hline $\mathrm{H}^{+}(\mu \mathrm{mol} / \mathrm{h})$ & $113 \pm 9$ & $89 \pm 12$ & $61 \pm 10^{*}$ & $28 \pm 9^{*}$ & $11 \pm 6^{*}$ & $11 \pm 3^{*}$ & $12 \pm 2^{*}$ \\
\hline \multicolumn{8}{|c|}{ Intraduodenal omeprazole $(\mu \mathrm{mol} / \mathrm{kg})$} \\
\hline & Control & 1.25 & $2 \cdot 5$ & 5 & 10 & 50 & \\
\hline n & 11 & 9 & 9 & 9 & 9 & 10 & \\
\hline $\mathrm{H}^{\div}(\mu \mathrm{mol} / \mathrm{h})$ & $62 \pm 17$ & $62 \pm 7$ & $41 \pm 11$ & $43 \pm 15$ & $21 \pm 7^{*}$ & $4 \pm 3^{*}$ & \\
\hline \multicolumn{8}{|c|}{ Intragastric omeprazole ( $\mu \mathrm{mol} / \mathrm{kg}$ ) } \\
\hline & Control & & & 5 & & 50 & \\
\hline n & 7 & & & 8 & & 8 & \\
\hline $\mathrm{H}^{+}(\mu \mathrm{mol} / \mathrm{h})$ & $131 \pm 37$ & & & $96 \pm 30$ & & $1 \pm 1^{*}$ & \\
\hline
\end{tabular}

${ }^{*} \mathrm{p}<0.05$ Mann-Whitney test comparing control group with treatment group.

produced almost total inhibition of acid secretion but the effect of the $5 \mu \mathrm{mol} / \mathrm{kg}$ failed to reach statistical significance on Mann-Whitney testing.

\section{CYTOPROTECTIVE STUDIES}

Intraperitoneal cimetidine (after pyloric ligation)

The effect of intraperitoneal cimetidine on acute gastric mucosal lesions produced by topical acidified aspirin suspension is shown in Figure 1a. Progressive reduction in mean lesion score was produced by doses ranging from $2 \mathrm{mg} / \mathrm{kg}$ to $100 \mathrm{mg} / \mathrm{kg}$ of cimetidine. Eighty three per cent of the stomachs in the control group contained one or more lesions and mean lesion score was $23 \cdot 7 \pm 3 \cdot 5$. Individual MannWhitney tests between the control group and each treatment group showed that only the $50 \mathrm{mg} / \mathrm{kg}$ and $100 \mathrm{mg} / \mathrm{kg}$ groups differed significantly from the controls. Mean lesion scores of these two treatment groups were $6.9 \pm 2.52$ and $3.5 \pm 2 \cdot 1$ respectively with $36 \%$ and $27 \%$ of the stomachs containing lesions. Two hundred and fifty milligrams per kilogram of cimetidine failed to reduce mean lesion score significantly from control values, despite a maximum effect on acid secretion in the secretory studies. Analysis of variance showed that the seven groups differed significantly $(p<0.005)$ in terms of lesion scores.

The effect of intraperitoneal cimetidine on mucosal lesions produced by topical acidified sodium taurocholate solution is shown in Figure 1b. Ninety seven per cent of the stomachs in the control group contained lesions and mean lesion score was $32 \cdot 7 \pm 4 \cdot 3$. Significant reductions in lesion scores were produced by $10 \mathrm{mg} / \mathrm{kg}$ and $25 \mathrm{mg} / \mathrm{kg}$ of cimetidine resulting in mean scores of $10.8 \pm 3.3$ and $15 \cdot 5 \pm 3 \cdot 8$ respectively with $62 \%$ and $68 \%$ of the stomachs containing lesions. Increasing doses of cimetidine resulted in a progressive loss of cyto-
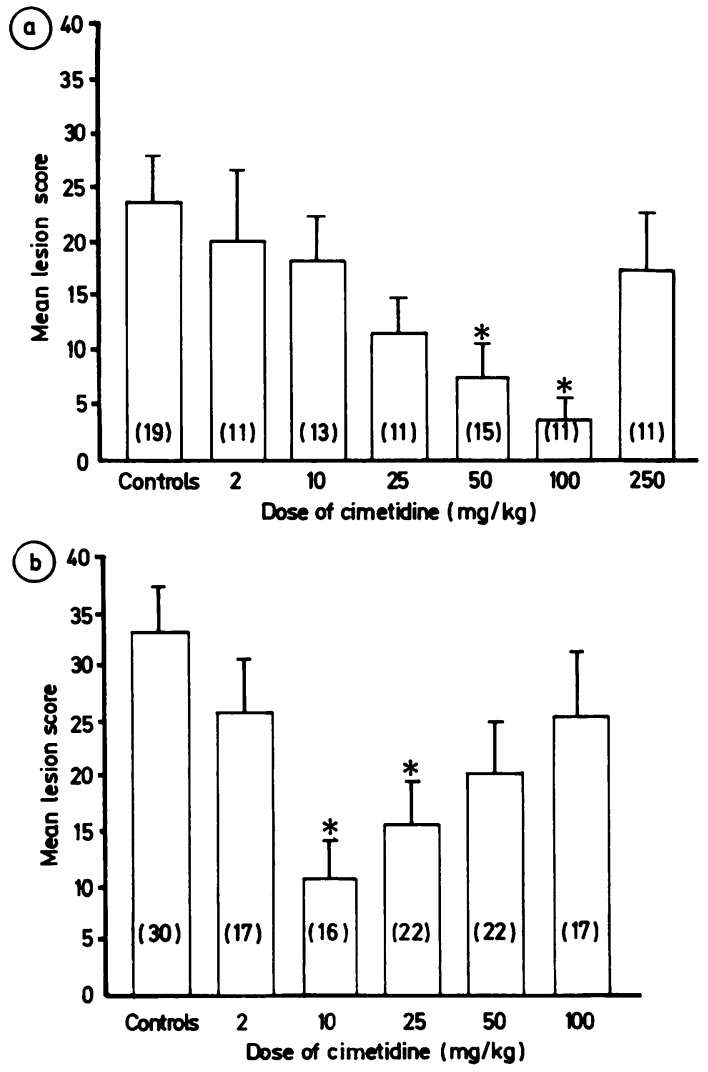

Fig. 1a, b Effect of intraperitoneal cimetidine on gastric mucosal lesions produced by (a) topical acidified aspirin, and (b) topical acidified sodium taurocholate in the pylorus ligated rat. Results are illustrated as the mean $\pm S E M$, the number in parentheses represent the number of rats in each group, and the asterisks represent $p<0.05$ (Mann-Whitney test comparing control group with treatment group). 
protection from $10 \mathrm{mg} / \mathrm{kg}$ to $100 \mathrm{mg} / \mathrm{kg}$ despite an increasing antisecretory effect. Analysis of variance showed that the six groups differed significantly $(p<0.01)$ in terms of lesion scores.

\section{Intraduodenal omeprazole (after pyloric ligation)}

The effect of intraduodenal omeprazole on aspirininduced mucosal lesions is shown in Figure 2a. None of the treatment groups differed significantly from the control group and analysis of variance showed no significant difference. In the control group $87 \%$ of the stomachs contained lesions and in the treatment groups the incidence ranged from $90 \%$ to $78 \%$.

The effect of intraduodenal omeprazole on taurocholate-induced mucosal lesions is shown in Figure 2b. Mean lesion scores in the treatment groups did not differ significantly from the control value and
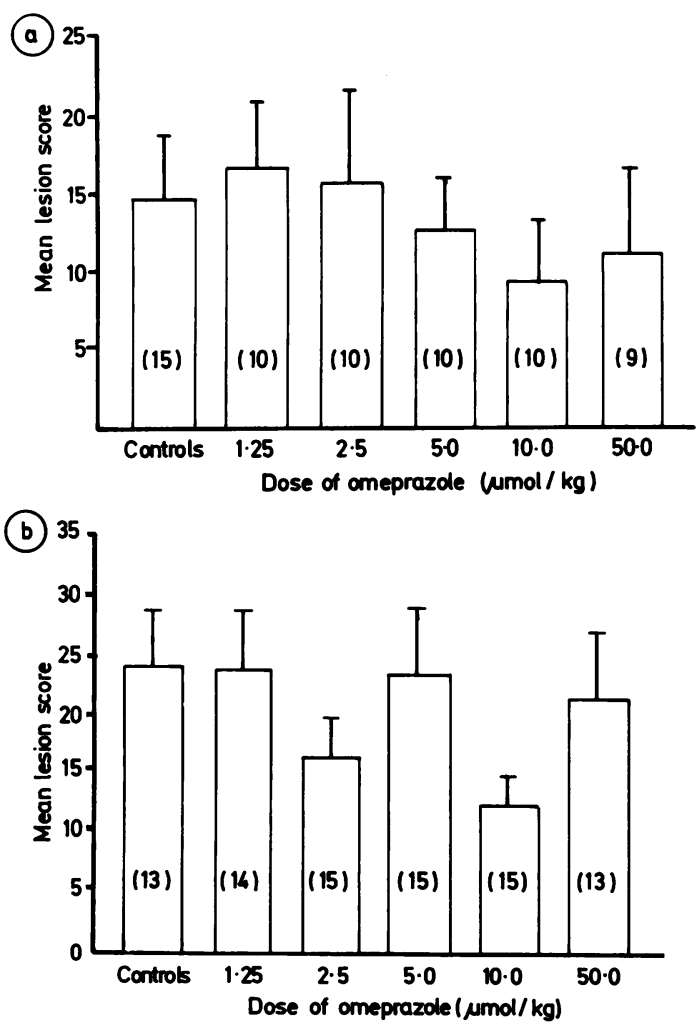

Fig. 2a, b Effect of intraduodenal omeprazole on gastric mucosal lesions produced by (a) topical acidified aspirin, and $(b)$ topical acidifed sodium taurocholate in the pylorus ligated rat. Results are illustrated as the mean $\pm S E M$ and the number in parentheses represent the number of rats in each group. analysis of variance showed no significant difference. In the control group $100 \%$ of the stomachs contained lesions and in the treatment groups the incidence ranged from $93 \%$ to $77 \%$.

\section{Intragastric omeprazole (30 minutes before pyloric} ligation)

The effect of intragastric omeprazole on aspirin induced mucosal lesions is shown in Figure 3. Omeprazole failed to reduce mean lesion score significantly from a control value of $27.4 \pm 7 \cdot 8$ and an incidence of $100 \%$. Five micromoles per kilogram and $50 \mu \mathrm{mol} / \mathrm{kg}$ of omeprazole resulted in mean lesion scores of $31 \cdot 0 \pm 6 \cdot 3$ and $25 \cdot 1 \pm 6 \cdot 6$ respectively with $100 \%$ and $90 \%$ of the stomachs containing lesions.

\section{Discussion}

The results of the present study confirm previous reports that cimetidine protects against mucosal ulceration in experimental models. ${ }^{4} 89$ Guth et $a l,{ }^{4}$ however, showed cytoprotection in that mean lesion scores were significantly reduced by doses of

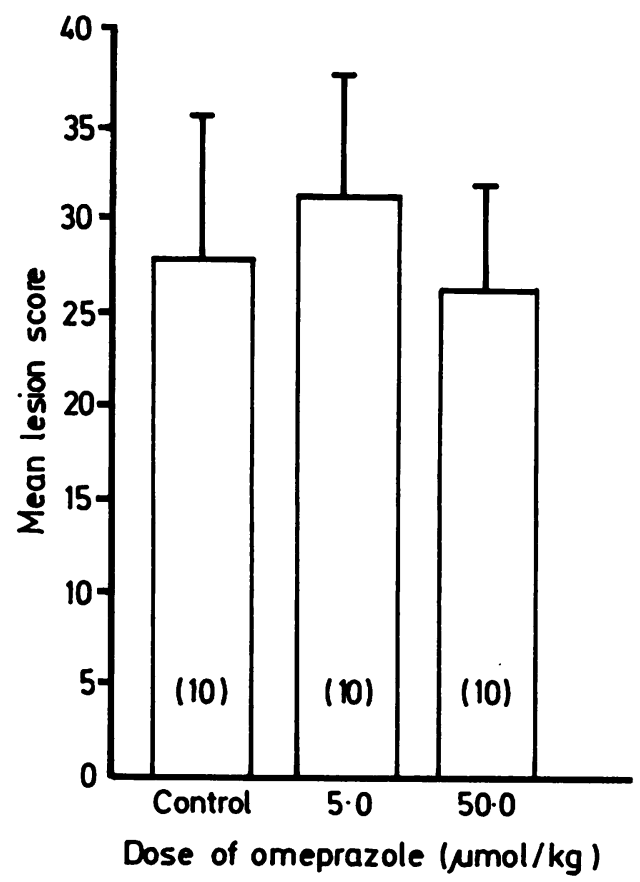

Fig. 3 Effect of intragastric omeprazole administered 30 minutes before pyloric ligation on gastric mucosal lesions produced by topical acidified aspirin in the rat. Results are illustrated as the mean $\pm S E M$ and the numbers in parentheses represent the number of rats in each group. 
cimetidine with and without antisecretory activity $(50 \mathrm{mg} / \mathrm{kg}$ and $2.5 \mathrm{mg} / \mathrm{kg})$. In the present study 2 $\mathrm{mg} / \mathrm{kg}$ cimetidine had no significant effect on acid secretion or on mucosal injury induced by either topical acidified aspirin or taurocholate. Mucosal protection was shown only by doses of cimetidine that significantly reduced acid secretion, a finding similar to that of Robert et al. ${ }^{3}$ With increasing doses of cimetidine, however, this protective effect was lost, despite continuing antisecretory activity.

Pylorus ligation is a known stimulus for acid secretion in the rat and although the mechanism is uncertain it probably involves a vagovagal reflex. ${ }^{10}$ After pyloric ligation, Hakanson et al ${ }^{11}$ were unable to produce further stimulation of $\mathrm{H}^{+}$secretion with doses of pentagastrin up to $250 \mu \mathrm{g} / \mathrm{kg}$. In the present study exogenous acid was given intragastrically to ensure that any observed 'cytoprotection' was not merely a consequence of cimetidine's ability to suppress endogenous $\mathrm{H}^{+}$secretion. The loss of protection with increasing antisecretory doses of cimetidine confirms the independence of acid secretion and cytoprotective activity of this experimental model. The reason for this loss of protection is unclear but possible mechanisms include a nonspecific toxic action of cimetidine, an influence on gastric mucosal blood flow, or alteration in the mucus-bicarbonate barrier with reduction in the $\mathrm{pH}$ gradient across the surface mucus layer.

Recent experimental evidence suggests that the gastric mucosa may be protected against injury by maintaining a $\mathrm{pH}$ gradient across an 'unstirred layer' of mucus. Using an antimony microelectrode Takeuchi et al $^{12}$ have measured the $\mathrm{pH}$ gradient and thickness of the mucus gel layer in amphibian gastric fundic mucosa in vitro and have studied the effect of luminal $\mathrm{pH}$, nutrient $\left[\mathrm{HCO}_{3}{ }^{-}\right]$and a variety of drugs on the $\mathrm{pH}$ gradient and mucus thickness. 16,16dimethyl prostaglandin $E_{2}$ increased the thickness of the mucus gel and a similar study by Ross and Turnberg ${ }^{13}$ showed that pretreatment of the rat mucosa with 16,16 -dimethyl prostaglandin $\mathrm{E}_{2}$ significantly increased maximum $\mathrm{pH}$ within the mucus layer, suggesting stimulation of $\mathrm{HCO}_{3}^{-}$production by the underlying epithelium. The effect of increasing doses of cimetidine on the mucus bicarbonate barrier has not been studied in this experimental model but Kenyọn et al $^{14}$ were unable to show siginificant net flux of $\mathrm{Na}^{+}$and $\mathrm{H}^{+}$ions in vagallydenervated pouches of antrectomised dogs, although the doses of cimetidine were much small than those used in the present study. Further studies are required to examine the effect of increasing doses of cimetidine on the mucus-bicarbonate barrier.

O'Brien and Silen ${ }^{7}$ have suggested that the secretory status of the mucosa, and hence its acid-base status, are important determinants in the tolerance of the tissue to exogenous back diffusion of $\mathrm{H}^{+}$. By inducing back diffusion of $\mathrm{H}^{+}$into burimamide-inhibited amphibian gastric mucosa, a marked depression of the potential difference, electrical resistance, and short circuit current was observed indicating severe compromise of active transport processes and increased permeability. The results were similar whether $\mathrm{H}^{+}$back diffusion was induced by an electric current, a concentration gradient, or by topical sodium taurocholate. Spontaneous secretion appeared to increase the tolerance of the mucosa to $\mathrm{H}^{+}$back diffusion.

In the present study the effect of cimetidine on taurocholate-induced mucosal lesions support the findings of O'Brien and $\mathrm{Silen}^{7}$ in the sense that progressive loss of mucosal protection was observed with doses of cimetidine that caused increasing inhibition of acid secretion. Maximal protection against aspirin-induced mucosal injury, however, was achieved with doses of cimetidine $(50 \mathrm{mg} / \mathrm{kg}$ and $100 \mathrm{mg} / \mathrm{kg}$ ) which also showed maximal inhibition of $\mathrm{H}^{+}$secretion.

Omèprazole, a substituted benzimidazole, is a new long acting, potent, and highly specific inhibitor of gastric acid secretion. Unlike cimetidine it appears to act by specific non-competitive interaction with the gastric 'proton-pump', blocking $\left(\mathrm{H}^{+}+\mathrm{K}^{+}\right)$ATPase located in the secretory membrane of the parietal cell. ${ }^{15}$ Its antisecretory action has been confirmed ${ }^{16-19}$ and the compound has been shown to prevent ulcer formation by a variety of methods, including pylorus ligation and exposure to aspirin solution..$^{20}$ Inhibition of acute ulcer formation and accelerated ulcer healing, however, are thought to be due mainly to omeprazole's potent and sustained antisecretory activity, ${ }^{20}$ and any cytoprotective properties have yet to be confirmed. Contrary to the preliminary reports by Konturek $e t$ $a l^{21}$ and Kollberg $e t a l,{ }^{22}$ the present study did not show a cytoprotective effect of omeprazole given either intraduodenally at the time of instillation of acidified aspirin or taurocholate, or when given intragastrically 30 minutes before aspirin. Konturek et $a l^{21}$ reported that intragastric omeprazole afforded dose dependent protection against the production of gastric lesions produced by acidified aspirin in the rat. This prevention was achieved with a dose of omeprazole which did not affect acid secretion and which was given 30 minutes before aspirin. Omeprazole given intragastrically in doses ranging from $0.2 \mu \mathrm{mol} / \mathrm{kg}$ to $20 \mu \mathrm{mol} / \mathrm{kg}$ failed to affect the formation of gastric lesions induced by topical absolute ethanol. Kollberg et al, ${ }^{22}$ however, showed that dose-dependent protection against 
topical ethanol induced damage could be conferred by intragastric omeprazole given five minutes prior to ethanol. The doses of omeprazole used were greater than those used by Konturek et al, ${ }^{21}$ and statistical significance was achieved only at doses of $40 \mu \mathrm{mol} / \mathrm{kg}$ and $100 \mu \mathrm{mol} / \mathrm{kg}$ omeprazole. Intraperitoneal omeprazole failed to cytoprotect in doses of $10 \mu \mathrm{mol} / \mathrm{kg}$ and $40 \mu \mathrm{mol} / \mathrm{kg}$.

In conclusion, the results of the present study suggest that $\mathrm{H}_{2}$ receptor antagonist, cimetidine, can protect the pylorus ligated rat against mucosal injury induced by topical aspirin or taurocholate. Although this protective effect of cimetidine was observed only with doses that were antisecretory, they were observed in the presence of exogenous $\mathrm{H}^{+}$and the dose response curves show that the antisecretory and cytoprotective activity are independent mechanisms. In this experimental model omeprazole failed to exhibit cytoprotective effect despite its antisecretory activity.

\section{References}

1 Robert A, Nezamis JE, Lancaster C, Hanchar AJ. Cyto-protection by prostaglandins in rats. Gastroenterology 1979; 77: 433-43.

2 Carmichael HA, Nelson LM, Russell RI. Cimetidine and prostaglandin: Evidence for different modes of action on the rat gastric mucosa. Gastroenterology 1978; 4: 1229-32.

3 Robert A, Hanchar AJ, Nezamis JE, Lancaster C. Cyto-protection against acidified aspirin: comparison of prostaglandin, cimetidine and probanthine. Gastroenterology 1979; 76: 1227.

4 Guth PH, Aures D, Paulsen G. Topical aspirin plus $\mathrm{HCl}$ gastric lesions in the rat. Gastroenterology 1979; 76: 88-93.

5 Kauffman GL, Grossman MI. Prostaglandin and cimetidine inhibit the formation of ulcers produced by parenteral salicylates. Gastroenterology 1978; 75: 1099-102.

6 O'Brien PE, Carter DC. Effect of gastric secretory inhibitors on the gastric mucosal barrier. Gut 1975; 16: 437-42.

7 O'Brien PE, Silen W. Influence of acid secretory state on the gastric mucosal tolerance to back diffusion of
$\mathrm{H}^{+}$. Gastroenterology 1976; 71: 760-5.

8 Bommelaer G, Guth PH. Protection by histamine receptor antagonists and prostaglandin against gastric mucosal barrier disruption in the rat. Gastroenterology 1979; 77: 303-8.

9 Bunce KT, Daly MJ, Humphray JM, Stables R. $\mathrm{H}_{2}$-receptor antagonists protect against aspirin-induced gastric lesions in the rat. Agents Actions 1981; 11: 167-70.

10 Brodie DA. The mechanism of gastric hyperacidity produced by pylorus ligation in the rat. $\mathrm{Am} \mathrm{J} \mathrm{Dig} \mathrm{Dis}$ 1966; 11: 231-41.

11 Hakanson R, Hedenbro J, Liedberg G, Sundler F, Vallgren S. Mechanisms of gastric acid secretion after pylorus and oesophageal ligation in the rat. $J$ Physiol 1980; 305: 139-49.

12 Takeuchi K, Magee D, Critchlow J, Matthews J, Silen W. Studies of the $\mathrm{pH}$ gradient and thickness of frog gastric mucus gel. Gastroenterology 1983; 84: 331-40.

13 Ross IN, Turnberg LA. Studies of the 'mucus bicarbonate' barrier on rat fundic mucosa: the effects of luminal $\mathrm{pH}$ and a stable prostaglandin analogue. Gut 1983; 24: 1030-3.

14 Kenyon GS, Ansell IF, Carter DC. Cimetidine and the gastric mucosal barrier. Gut 1977; 18: 631-5.

15 Fellenius E, Berglindh T, Sachs G et al. Substituted benzimidazoles inhibit gastric acid secretion by blocking $\left(\mathrm{H}^{+}+\mathrm{K}^{+}\right)$ATPase. Nature 1981; 290: 159-61.

16 Olbe L, Haglund U, Leth R et al. Effects of substituted benzimidazole ( $\mathrm{H} \mathrm{149/94)}$ on gastric acid secretion in humans. Gastroenterology 1982; 83: 193-8.

17 Lind T, Cederberg C, Ekenved G, Haglund U, Olbe L. Effect of omeprazole - a gastric proton pump inhibitor - on pentagastrin stimulated acid secretion in man. Gut 1983; 24: 270-6.

18 Walt RP, Gomes FA, Wood EC, Logan LH, Pounder RE. Effect of daily oral omeprazole on 24 hour intragastric acidity. $\mathrm{Br}$ Med J 1983; 287: 12-14.

19 Utley RJ, Wright R, Carter DC. Effect of omeprazole on insulin induced gastric secretion in man. Scott Med J (In press).

20 Yamamoto O, Okada Y, Okabe S. Effects of a proton pump inhibitor, omeprazole and gastric secretion and gastric and duodenal ulcers or erosions in rats. Dig Dis Sci 1984; 29: 394-401.

21 Konturek SJ, Cieszkowski M, Kwiecien N, Brozowski T. Gastric antisecretory and protective effects of omeprazole. Gastroenterology 1983; 84: 1213.

22 Kollberg B, Isenberg JI, Johansson C. Oral omeprazole protects gastric mucosa against ethanol. Gastroenterology 1983; 84: 1212. 